\title{
Accelerated Shelf Life Study of AKJ-1 (Atharga kempu jola) Red Sorghum Flakes Based Low Glycemic Index Snack Bar
}

\author{
Sandya S. Ryavanki* and S. Hemalatha \\ Department of Food Science and Nutrition, College of Rural Home Science, University of \\ Agricultural Sciences, Dharwad - 580005, Karnataka, India \\ *Corresponding author
}

\section{Keywords}

Shelf life, Free fatty acid, Moisture,

Organoleptic

evaluation, Snack bar

Article Info

Accepted:

04 February 2018

Available Online:

10 March 2018

\section{A B S T R A C T}

To provide an alternative sweet snack for the benefit of diabetic subjects, functional low glycemic index red sorghum flakes based snack bar was developed. Red sorghum [Atharga keтри jola (AKJ-1)] was procured from All India Co-ordinated Sorghum Improvement Project, Reglycemic indexonal Agricultural Research Station, Vijayapur and other ingredients were procured from local market. Storage quality of designed snack bar was assessed by accelerated shelf life method. Sorghum flakes based low glycemic index snack bars weighing $100 \mathrm{~g}$ was used for LD polyethylene packaging material and storage. Three laminated LD polyethylene packaging material was used for storage studies. Accelerated storage study was carried out where one set of packets were stored in a humidity oven (60 ${ }^{\circ} \mathrm{C}$, RH $80 \pm 2$ ) and the other set was stored at ambient temperature for 15 days. Samples were drawn for chemical analysis and sensory evaluation at regular intervals of three days. Significant decrease in all the sensory attributes of sample stored at $60^{\circ} \mathrm{C}$ were observed from initial (8.80) to fifteenth day (5.20) whereas no significant difference was observed in the samples stored at ambient temperature from initial (8.80) to fifteenth day (7.50). The result of chemical analysis found that significant increase in the moisture $(6.12-7.93)$ and free fatty acid content $(1.36-6.16)$ in the samples stored at humidity oven $\left(60{ }^{\circ} \mathrm{C}\right)$ whereas no significant difference was found in samples stored at ambient temperature $\left(30^{\circ} \mathrm{C}\right)$. Shelf life of the product determined by $\mathrm{Q}_{10}$ values revealed that designed low glycemic index snack bar could be stored for 2.65 months at ambient temperature.

\section{Introduction}

Sorghum (Sorghum bicolour L. moench) is one of the major cereal crop consumed in India after rice (Oryza sativa) and wheat (Triticum aestivium). It is an important portion in diets of millions of people. It is one of the nutritionally recognised crop that provides 349 Kcal energy, 73.25 per cent carbohydrates, 2.41 per cent ash and 11.12 per cent moisture content (Chavan et al., 2015). Sorghum is a good source of dietary fibre.

It is known that fibre intakes are associated with lower serum cholesterol concentrations, lower risk of coronary heart disease, reduced blood pressure, enhanced weight control, better glycemic control, reduced risk of certain forms of cancer and improved gastrointestinal functions (James et al., 1994). 
Snack bars are one of the ready to eat convenient foods with long shelf life occupying larger space in the consumer market which not only satisfy the hunger, but has been proven as a quality source of nutrients and a convenient means of replacement of a meal. The most commonly used ingredients in the snack bars are oats, wheat or rice and soya. Busy life styles and the increasing demand from consumers for meals and snacks that are quick sources of good nutrition have prompted the food industry to develop foods like nutrition bars that combine convenience and nutrition (Izzo and Niness, 2001). The cereal bars have gained an acceptance in the consumer's eyes as being "better for you" and good in nutritional terms, from the contribution of an amount of dietary fibre. The popularity of these products reflects nutritional guidelines recommending increased dietary fibre intake since low fibre consumption has been implicated as a risk factor in many diseases (Murphy, 2001).

As snack bars are popular convenient foods with long shelf life, selection of proper packaging materials is most essential to ensure maximum product quality during storage. These ready-to-eat foods are most susceptible to lipid oxidation, irrespective of lipid content, acquire considerable flavour and odour, reduce sensory perception, nutritional quality and safety of foods during storage, and make the food unpalatable. Therefore extension of shelf life and preservation of ready-to-eat foods is of utmost importance. Food packaging plays a vital role in determining the shelf life of foods as they act as a barrier for oxygen and loss or gain of moisture in foods. Selection of a proper packaging material is most essential to ensure maximum product quality during storage to prevent oxidation of lipids (Padmashree et al., 2013). Hence the present study was conducted to assess the storage quality of the low glycemic index sorghum flakes based snack bar.

\section{Materials and Methods}

\section{Processing of grains}

Red sorghum genotype Atharga kempu jola (AKJ-1) was procured from All India Coordinated Sorghum Improvement Project, Regional Agricultural Research Station, Vijayapur, UAS, Dharwad. The samples were collected at one lot, processed and used for the studies. Flaking process of red sorghum grains was carried out at Bhavani Foods and Feeds, Vijayapur.

\section{Preparation of snack bar}

Red sorghum flakes based low glycemic index snack bar was developed using basic recipe given by Ribanar, 2014. Red sorghum flakes constituted the main ingredient and other ingredients such as flaxseed, honey, skimmed milk powder, unsalted butter etc were added either as binding substances, sweetener, carbohydrate, protein and energy constituents.

\section{Accelerated shelf life study}

Sorghum flakes based snack bars with low glycemic index weighing $100 \mathrm{~g}$ were used for packaging and storage. Three laminated LD packaging material was selected for storage studies. Accelerated storage study was carried out where one set of packets were stored in a humidity chamber $\left(60^{\circ} \mathrm{C}, \mathrm{RH} 80 \pm 2\right)$ and the other set was stored at ambient temperature for 15 days. After every three days interval, samples were drawn for analysis and sensory evaluation. During storage care was taken to keep samples free from pest attack. Samples were randomly collected for analysis during the storage period.

\section{Analysis of stored samples}

The samples were withdrawn at regular intervals of three days and analyzed for the 
parameters viz., moisture content, free fatty acids and organoleptic evaluation.

\section{Moisture content (\%)}

Moisture content was determined by taking 10 $\mathrm{g}$ of sample in moisture cup and dried in an oven at $105{ }^{\circ} \mathrm{C}$ till the weight of the moisture cup with its content was constant. After removing from the oven, before weighing the moisture cup was cooled in desiccator. Moisture content of the sample was expressed in percentage and computed as follows (Anonymous, 2005)

Initial weight of the sample Final weight of the sample Moisture content $(\%)=-x 100$

Weight of the sample

\section{Free fatty acids (\%)}

It was estimated by titrating the sample against potassium hydroxide in the presence of phenolphthalein indicator. Fat extract of 2-5 $\mathrm{ml}$ in a conical flask was added with $50 \mathrm{ml}$ of neutral alcohol and 3-4 drops of Phenolphthalein indicator.

The contents were titrated against N/10 KOH solution, until the pink colour which appeared persisted for 30 seconds.

FFA $(\%)=\frac{\mathrm{S} \times \mathrm{N} \times 56.2}{\text { Weight of fat }(\mathrm{g})}$

Where,

$\mathrm{S}=\mathrm{ml}$ of $\mathrm{KOH}$ solution

$\mathrm{N}=$ Normality of $\mathrm{KOH}$ solution

\section{Organoleptic evaluation}

This was carried out by semi trained panelists using 9- point hedonic scale.

\section{Prediction of shelf life}

Shelf life of the product was determined by $\mathrm{Q}_{10}$ values. $\mathrm{Q}_{10}$ is the factor by which the rate of reaction increased when the temperature was raised by 10 degrees (Ramalingam et al., 2010).

\section{The rule of Ten $\left(Q_{10}\right)$}

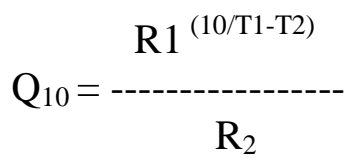

Where,

$\mathrm{T}=$ Temperature $\left({ }^{0} \mathrm{C}\right)$

$\mathrm{R}_{1}=$ Rate of reaction at $\mathrm{T}_{1}$

$\mathrm{R}_{2}=$ Rate of reaction at $\mathrm{T}_{2}$

\section{Results and Discussion}

Quality of optimized red sorghum flakes based snack bar with low GI stored in three laminated LD at two different conditions (accelerated and ambient) was observed at three days of interval for change in moisture, free fatty acid and organoleptic quality throughout storage period (15 days).

\section{Moisture and free fatty acid content}

Table 1 depicts the variation in the moisture and free fatty acid content during storage period (15 days). Moisture content of the snack bar significantly $(\mathrm{p} \leq 0.05)$ increased with increase in number of days. Moisture content of low GI bar kept in humidity oven (accelerated condition) ranged from $6.12 \pm$ 0.17 to $7.93 \pm 0.35$ per cent and at ambient temperature $6.12 \pm 0.17$ to $6.36 \pm 0.15$ per cent. Free fatty acid of snack bar in humidity oven (accelerated condition) ranged from 1.36 \pm 0.42 to $6.16 \pm 0.45$ per cent. However at ambient temperature it was $1.36 \pm 0.42$ to 2.37 \pm 0.25 per cent. Both moisture and free fatty 
acid content was significantly high in samples stored at accelerated conditions than samples stored at ambient condition.

\section{Organoleptic evaluation}

Low GI snack bars stored at two different conditions (accelerated and ambient) was subjected to organoleptic evaluation by 10 semi- trained panelists at every $3^{\text {rd }}$ day interval for attributes such as appearance, colour, flavor, texture, taste and over all acceptability (Fig. 1).

The scores for appearance of snack bars stored at both the conditions differed significantly throughout the storage period.

Scores for appearance of snack bars stored at accelerated conditions gradually decreased from initial days (8.80) of storage viz., 3 days (8.30), 6 days (7.80), 9 days (7.10), 12 days (6.30) and 15 days (5.20). Whereas snack bars stored at ambient condition had scores above eight during all the intervals but decreased at $15^{\text {th }}$ day with scores below seven.

Decreasing trend was observed for scoring of colour during the storage of both the snack bars under accelerated and ambient condition. Sorghum flakes based snack bar stored at accelerated condition decreased from 8.60 to 6.00 and at ambient temperature from 8.60 to 7.10. There was significant difference in score on the subsequent days of storage days in the snack bars. During storage it was observed that samples stored at accelerated conditions were darker than the samples stored at ambient temperature.

The organoleptic scores for change in flavour of snack bar stored at accelerated condition gradually decreased from 8.60 to 6.00 whereas scores for snack bar stored at ambient temperature ranged from 8.60 to 7.10 throughout the storage period of 15 days.
Taste of the snack bars stored at ambient temperature maintained scores above eight till 12 days of storage and decreased (7.40) at the end of the $15^{\text {th }}$ day. But snack bars stored at accelerated condition significantly decreased from initial (8.70) to end of the $15^{\text {th }}$ day (5.10). It was observed that in accelerated conditions the samples drawn at $15^{\text {th }}$ day of storage was not acceptable.

Organoleptic evaluation scores for texture of the snack bars stored at different conditions depicted that texture of the snack bar stored at ambient condition maintained scores above eight till $9^{\text {th }}$ day then decreased to 7.50 after $15^{\text {th }}$ day where as in accelerated condition texture was significantly decreased from 8.50 to 5.10 at the end of the $15^{\text {th }}$ day. Over all acceptability scores gradually decreased in samples at both the conditions where as significant decrease was found in case of accelerated condition (8.80 - 5.20) but in case of ambient temperature no much difference was observed $(8.80-7.50)$.

\section{Prediction of shelf life}

Rate of reaction for moisture at $60{ }^{0} \mathrm{C}$ was 0.12 and at $30{ }^{0} \mathrm{C}$ was 0.01 . $\mathrm{Q}_{10}$ value for change in the moisture percentage was found to be 1.83. Similarly for free fatty acid, rate of reaction at $60{ }^{\circ} \mathrm{C}$ was 0.32 and at $30{ }^{\circ} \mathrm{C}$ it was 0.06. $\mathrm{Q}_{10}$ value for change in the free fatty acid content was found to be 1.65 . The mean predicted shelf life of the product at $30{ }^{\circ} \mathrm{C}$ (ambient) determined was 2.65 months (Table 2).

The optimized snack bar with low glycemic index was stored in three laminated LD pouches in humidity oven $\left(60{ }^{\circ} \mathrm{C}, \mathrm{RH} 80 \pm 2\right)$ and ambient temperature $\left(14-35{ }^{\circ} \mathrm{C}\right)$. During storage (0-15 days) the moisture content increased from 6.12 to 7.93 per cent and from 6.12 to 6.36 per cent in bars stored in humidity oven and at ambient temperature respectively. 
Table.1 Variations in moisture and free fatty acid content of low glycemic index red sorghum snack bar during storage period

\begin{tabular}{|c|c|c|c|c|c|c|c|}
\hline \multirow[t]{2}{*}{ Parameters } & \multirow{2}{*}{$\begin{array}{c}\text { Temperatur } \\
\text { e }\end{array}$} & \multicolumn{6}{|c|}{ Number of days of storage } \\
\hline & & 0 day & $3^{\text {rd }}$ day & $6^{\text {th }}$ day & $9^{\text {th }}$ day & $12^{\text {th }}$ day & $15^{\text {th }}$ day \\
\hline \multirow{2}{*}{$\begin{array}{c}\text { Moisture } \\
(\%)\end{array}$} & T1 & $6.12 \pm 0.17$ & $6.62 \pm 0.17$ & $6.98 \pm 0.15$ & $7.37 \pm 0.19$ & $7.67 \pm 0.08$ & $7.93 \pm 0.35$ \\
\hline & T2 & $6.12 \pm 0.17$ & $6.16 \pm 0.06$ & $6.18 \pm 0.15$ & $6.25 \pm 0.14$ & $6.26 \pm 0.06$ & $6.36 \pm 0.15$ \\
\hline \multicolumn{2}{|c|}{ F value } & $0.00^{\mathrm{NS}}$ & $20.21 * *$ & $40.82 * *$ & $71.21 * * *$ & $643.29 * * *$ & $51.07 * *$ \\
\hline \multicolumn{2}{|c|}{ S.Em \pm} & - & 0.18 & 0.20 & 0.21 & 0.13 & 0.27 \\
\hline \multicolumn{2}{|c|}{ CD } & - & 0.51 & 0.57 & 0.58 & 0.38 & 0.75 \\
\hline \multirow{2}{*}{$\begin{array}{l}\text { Free fatty } \\
\text { acid }(\%)\end{array}$} & T1 & $1.36 \pm 0.42$ & $1.75 \pm 0.15$ & $2.62 \pm 0.36$ & $3.97 \pm 0.50$ & $5.41 \pm 0.21$ & $6.16 \pm 0.45$ \\
\hline & T2 & $1.36 \pm 0.42$ & $1.69 \pm 0.14$ & $1.78 \pm 0.16$ & $1.85 \pm 0.09$ & $2.11 \pm 0.05$ & $2.37 \pm 0.25$ \\
\hline \multicolumn{2}{|c|}{ F value } & $0.00^{\mathrm{NS}}$ & $0.30^{\mathrm{NS}}$ & $13.74 *$ & $51.94 * *$ & $725.17 * * *$ & $159.19 * * *$ \\
\hline \multicolumn{2}{|c|}{ S.Em \pm} & - & - & 0.27 & 0.31 & 0.20 & 0.31 \\
\hline \multicolumn{2}{|c|}{ CD } & - & - & 0.76 & 0.86 & 0.56 & 0.87 \\
\hline
\end{tabular}

T1- $60^{\circ} \mathrm{C}, 80 \pm 2 \mathrm{RH}, \mathrm{T} 2$ - ambient temperature, values are expressed in mean \pm S.D of triplicates, * -Significant at $\mathrm{p} \leq 0.1,{ }^{* *}$-significant at $\mathrm{p} \leq 0.05, * * *$ - significant at $\mathrm{p} \leq 0.001$ NS- Non significant

Table.2 Predicted shelf life of designed low glycemic index red sorghum snack bar

\begin{tabular}{|c|c|c|c|c|c|c|}
\hline Parameters & Treatments & 0 day & 15 day & $\begin{array}{c}\text { Rate of } \\
\text { reaction }\end{array}$ & $\begin{array}{c}\text { Q10 value } \\
\begin{array}{c}\text { Predicted shelf } \\
\text { life (months) }\end{array}\end{array}$ & 3.06 \\
\hline $\begin{array}{c}\text { Moisture } \\
(\%)\end{array}$ & T1 & $6.12 \pm 0.17$ & $7.93 \pm 0.35$ & 0.12 & 1.83 & 2.24 \\
\hline Free fatty & T2 & $6.12 \pm 0.17$ & $6.36 \pm 0.15$ & 0.01 & 1.65 & \\
\hline acid $(\%)$ & T1 & $1.36 \pm 0.42$ & $6.16 \pm 0.45$ & 0.32 & $\mathbf{2 . 6 5}$ \\
\hline
\end{tabular}

T1- $60{ }^{\circ} \mathrm{C}, 80 \pm 2 \mathrm{RH}$ and T2- ambient temperature

Fig.1 Organoleptic evaluation of red sorghum flakes based low glycemic index snack bar during storage
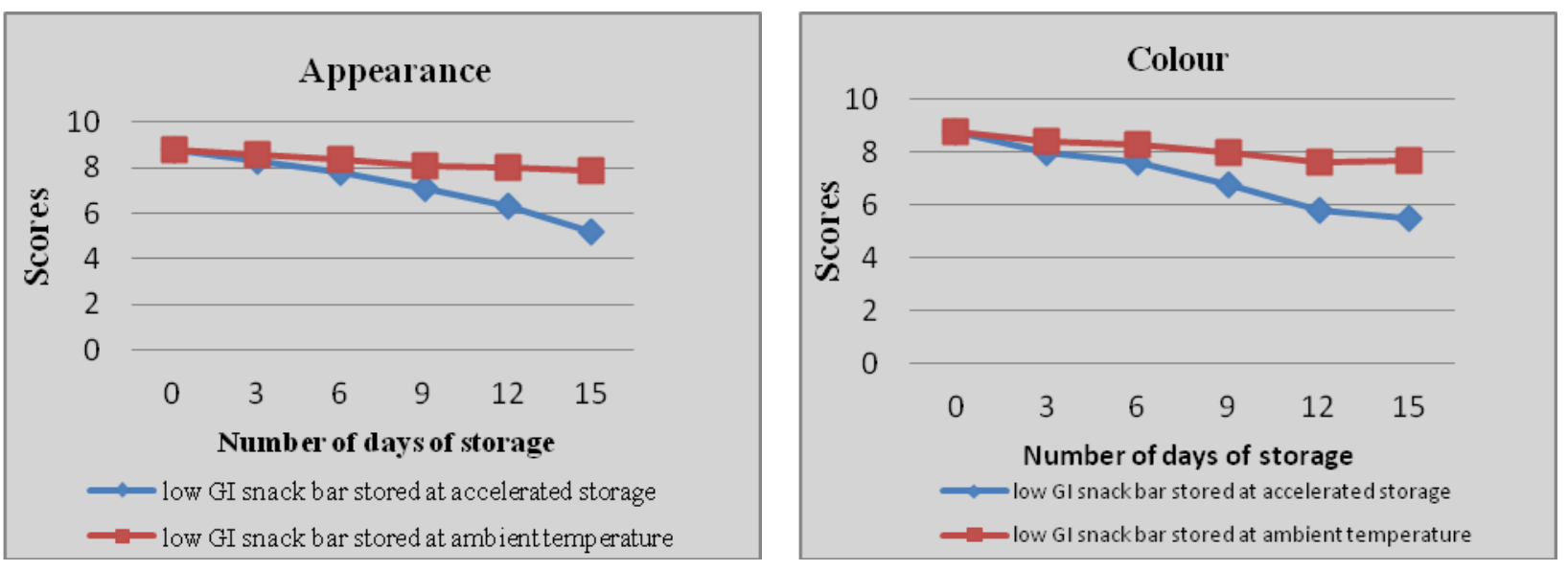

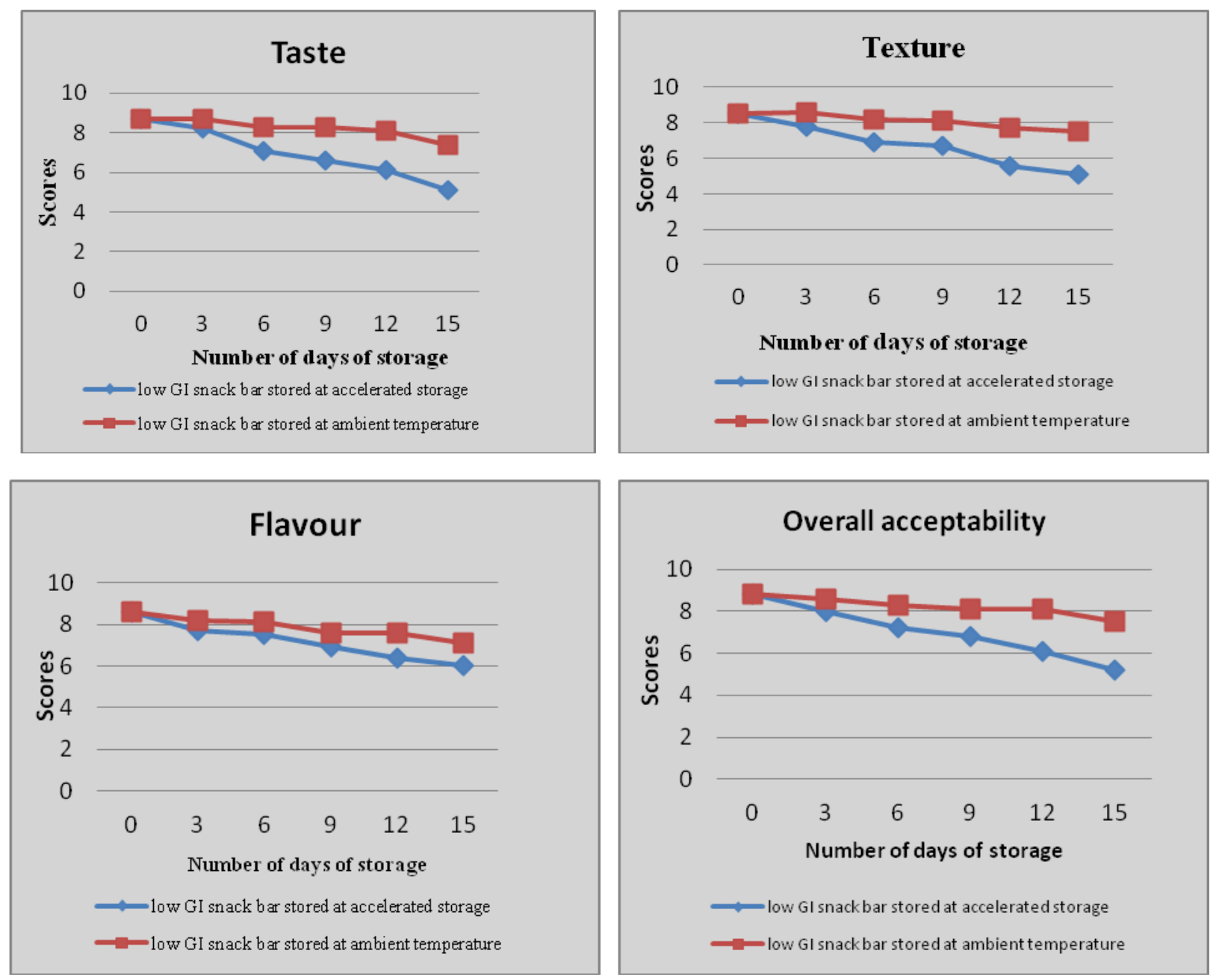

Over all there was about 1.81 and 0.24 per cent respectively moisture gain during 15 days of storage which indicates moisture gain of samples at accelerated condition was significantly higher compared to samples stored at ambient temperature indicating storage at high temperature and high relative humidity the products absorb moisture.

During storage, the samples stored in accelerated condition were darker compared to samples stored at ambient condition this might be due to high temperature and relative humidity which may cause maillard reaction and increase in water activity similar to what has been reported by Loveday et al., (2010) and Garcia et al., (2012). Texture of the snack bars was significantly different among both

the samples stored at accelerated and ambient conditions respectively. Samples stored at ambient temperature maintained good texture throughout the storage period of 15 days where as at accelerated condition texture of the snack bar was significantly decreased and scores reached below 5 at the end of $15^{\text {th }}$ day of storage. With increase in number of days of storage the softness of snack bars stored at accelerated condition was increased this might be due to rapid increase in the moisture content at high temperature noticed in the present study.

During storage period there was gradual decrease in scores of all the sensory attributes as well as overall acceptability. A cut off value of 7 on 9 point hedonic scale for over 
all acceptability score was decided for accepting the product during storage (Sharma et al., 2006). Based on this criterion snack bars stored at both the conditions (accelerated and ambient) were evaluated. The samples stored at ambient temperature maintained the sensory scores above 7 throughout the storage period of 15 days, whereas sensory scores of the samples stored at accelerated conditions gradually decreased with number of days of storage this might be due to change in the chemical composition and reaction of the ingredients used in the formulation at high temperature.

Considering organoleptic evaluation the product was acceptable for 15 days at accelerated condition. Based on these results the shelf life of the low glycemic index snack bar at ambient temperature was predicted. The calculated $\mathrm{Q}_{10}$ values were found to be in the range of 1.5 to 2.0 which was reported to be the range for lipid oxidation in various food products (Labuza and Riboh, 1982).

The results may have been influenced by the differences in water activity among the samples as the moisture content was found to be different during the experiments. The estimated shelf life of present designed low glycemic index snack bar at ambient temperature would be 2.6 months which is lesser than 8.7 months reported by Samsiah et al., (2011).

The study concludes that the designed low glycemic index AKJ-1 red sorghum flakes based snack bar packed in three laminated LD polyethylene pouches had a shelf life of 2.65 months.

The study limits to use of only one type of packaging material, however with different packaging material and with modified atmosphere packaging the shelf life probably could be extended.

\section{Acknowledgment}

I am extremely rejoiced to express my heartful gratitude and sincere thanks to my guide and my parents for their constant support. I also thank Department of Food Science and Nutrition, College of Rural Home Science, University of Agricultural Sciences for giving me the opportunity to conduct a valuable research.

\section{References}

Anonymous, 2005, Official Methods of Analysis of the Association of Official Analytical Chemists. $18^{\text {th }}$ edition, Washington, DC., USA.

Chavan, U. D., Patil, S. S., Rao, B. D. and Patil, J. V., 2015, Processing of sorghum for flakes and their products. European J. Mol. Biol. Biochem., 2(1): 49-58.

Garcia, M. C., Lobato, L. P., Benassi, M. T. and Junior, M. S. S., 2012, Application of roasted rice bran in cereal bars. Food Sci. Technol., 32(4):718- 724.

Izzo, M. and Niness, K., 2001, Formulating nutrition bars with inulin and oligofructose. Cereal Foods World, 46(3): 102-6.

James, W. A., Belinda, M. S. and Nancy, J. G., 1994, Health benefits and practical aspects of high fiber diets. American J. Clin. Nutr., 59: 1242-1247.

Labuza, T. P. and Riboh, D., 1982, Theory and application of Arrhenius kinetics to the prediction of nutrient losses in foods. Food Technol., 36: 66-74.

Loveday, S. M., Hindmarsh, J. P., Creamer, L. K. and Singh, H., 2010, Physicochemical changes in intermediate moisture protein bars made with whey protein or calcium caseinate. Food Res. Int., 43(5): 1321-1328.

Murphy, O., 2001, Non-polyol low digestible carbohydrates: food applications and 
functional benefits. British J. Nutr., 85: S47-S53.

Padmashree, A., Sharma, G. K. and Govindaraj, T., 2013, Development and evaluation of shelf stability of Flaxoat nutty bar in different packaging materials. Food Nutr. Sci., 4: 538-546.

Ramalingam, C., Mercy, P. I., Sweta, R. and Sonica, G., 2010, Development of tropical fruit bars and assessment of its shelf life. J.Experimental Sci., 1(7): 2632

Ribanar, A.A., 2014, Designing sorghum (Sorghum bicolor (L.) moench) flakes based snack bar for nutritional and health benefits of children. M. Sc. Thesis, Univ. Agric. Sci., Dharwad, Karnataka (India).

Samsiah, M. S., Azizah, A. N., Moey, S. W. and Latifah, M. S., 2011, Accelerated shelf life studies of high energy pineapple granola bar. Proc. $7^{\text {th }}$ Int. Pineapple Symp., Acta. Hort., 902, ISHS, pp. 539-546.

Sharma, G. K., Padmashree, A., Roopa, N. and Bawa, A. S., 2006, Storage stability of protein rich compressed bar. J. Food Sci. Technol., 43(4): 404-406.

\section{How to cite this article:}

Sandya S. Ryavanki and Hemalatha, S. 2018. Accelerated Shelf Life Study of AKJ-1 (Atharga keтри jola) Red Sorghum Flakes Based Low Glycemic Index Snack Bar. Int.J.Curr.Microbiol.App.Sci. 7(03): 275-282. doi: https://doi.org/10.20546/ijcmas.2018.703.032 